\title{
LEGAL AND POLICY FRAMEWORK OF EMPLOYMENT FOR PEOPLE WITH DISABILITIES IN LATVIA
}

Zaiga Oborenko ${ }^{1}$, Mg.hist., MSc., Baiba Rivza ${ }^{2}$, Dr.hab.oec

${ }^{1,2}$ Latvia University of Life Sciences and Technologies, Faculty of Economics and Social Development

\begin{abstract}
The European Union promotes the active inclusion and full participation of disabled people in society, defining raising the share of persons with disabilities in the open labour market as one of the priority action area. Employment of people with disabilities continues to be a topical subject with regard to the Latvian labour market. The paper deals with legal and policy frameworks of employment people with disability, social inclusion and non- discrimination as well as makes discussion on the study results regarding people with disability integration into the labour market. The state provides its support for the employment of disabled people and inclusion in the workplace through various initiatives and regulatory frameworks that are being explored in this publication. Although there are international, European Union and Latvian legal and regulatory frameworks and various policy planning initiatives, the inclusion of people with disabilities in the labour market still remains an open topic. As a result of the research, key areas of regulatory framework to improve employment and inclusion of disabled people in the labour market have been identified: the need to develop a motivating regulation for employers, to establish an effective mechanism for co-operation of different state institutions involved, to increase the responsibility of local municipalities and to develop a supportive intersectional cooperation mechanism to promote employment of people with disabilities.
\end{abstract}

Key words: legal framework, people with disabilities, fundamental right, discrimination, employment support system.

JEL code: E24, J71, K38

\section{Introduction}

One of the dominant features of legal thinking in twentieth century has been the recognition of law as a tool of social change. Although legislation is not the only means of social progress, it represents one of the most powerful vehicles of change, progress and development in society (UN, 2007). Persons with disabilities (PwD) often are excluded from the mainstream of the society and they have difficulties to be integrated in the labour market. While the importance and increasing role of international law in promoting the rights of persons with disabilities is recognised by the international community, domestic legislation remains one of the most effective means of facilitating social change and improving the status of disabled persons. International norms concerning disability are useful for setting common standards for disability legislation. Those standards also need to be appropriately reflected in policies and programmes that reach persons with disabilities and can effect positive changes in their lives (ibid.).

Quality jobs ensure economic independence, foster personal achievement, and offer the best protection against poverty. Having a job is fundamental to social inclusion, but employment opportunities of people with health problems or disability are limited. In the late-2000s, on average across the OECD countries employment rates of people with disabilities were just over $40 \%$ compared with $75 \%$ for people without disability (OECD, 2010). The rate of employment for people aged 15-65 having a basic activity difficulty is only $47 \%$ in average in European Union (Eurostat, 2011). For people with disabilities the rate of poverty is $70 \%$ higher than the average partly due to limited access to employment (EC, 2010). Employment and occupation are key elements in guaranteeing equal opportunities for all and contribute strongly to the full participation of citizens in economic, cultural and social life and to realising their potential as it is stated in EU Council Directive 2000/78/EC.

The difficult labour market integration of people with disability will create bigger problems in the future for many OECD countries given their rapidly changing demographics. Population ageing 
provides a solid argument for enhancing the efforts to mobilise the under-utilised labour potential among workers with disability. Higher participation rates for people with disability can help prevent future labour force declines. This can contribute to raising the productive capacity of the economy and reduce the costs associated with disability benefit programmes (OECD, 2010, p.23-26).

The employment of people with disabilities continues to be a topical subject with regard to the Latvian labour market. $37 \%$ of people with disabilities in working age $18-62$ are employed in Latvia (Ministry of Welfare, 2017). Although various policy and planning documents have been developed and various initiatives have been taken in Latvia in recent years, however, studies show that employment rate of people with disabilities is changing quite slightly (Figure 1 ).

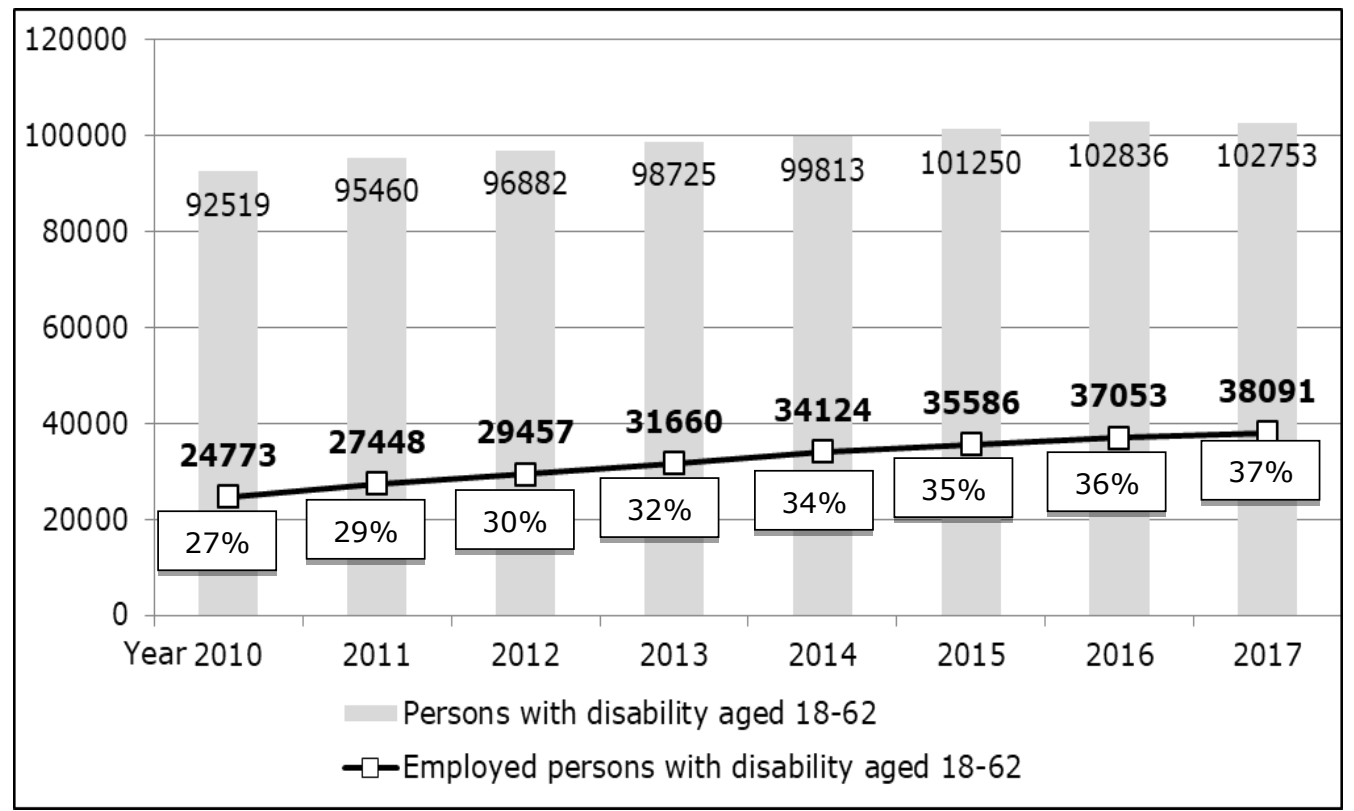

Source: authors' construction based on data of Ministry of Welfare

Fig. 1. Persons with disabilities at work age, number of employed persons

The economic growth in the country in 2017 has contributed to the decline in unemployment, thus registered unemployment as of 31 January 2018 was $7.0 \%$ (Table 1 ).

Unemployment rates in statistical regions of Latvia, 31 January 2018

Table 1

\begin{tabular}{|l|c|c|c|c|}
\hline $\begin{array}{c}\text { Statistical } \\
\text { regions }\end{array}$ & $\begin{array}{c}\text { Total number of } \\
\text { registered } \\
\text { unemployed }\end{array}$ & $\begin{array}{c}\text { Unemployment } \\
\text { rate \% }\end{array}$ & $\begin{array}{c}\text { Unemployed } \\
\text { PwD }\end{array}$ & $\begin{array}{c}\text { Unemployed PwD from } \\
\text { total unemployed in \% }\end{array}$ \\
\hline Riga & 12847 & 4,1 & 1067 & 8,3 \\
\hline Pieriga & 8665 & 4,4 & 815 & 9,4 \\
\hline Kurzeme & 9145 & 8,1 & 1312 & 14,3 \\
\hline Latgale & 20057 & 16,0 & 3544 & 17,7 \\
\hline Vidzeme & 6809 & 7,8 & 966 & 14,2 \\
\hline Zemgale & 7613 & 6,9 & 785 & 10,3 \\
\hline Total Latvia & $\mathbf{6 5 1 3 6}$ & $\mathbf{7 , 0}$ & $\mathbf{8 4 8 9}$ & $\mathbf{1 3 , 0}$ \\
\hline
\end{tabular}

Source: Data from State Employment Agency

With the resumption of economic growth in Latvia, demand for labour force is beginning to grow. It is projected that unemployment will continue to decrease, with the ever more active participation of the population in the labour market, which will be fuelled by an increasing opportunity to find work. In the case of lower unemployment, people with disabilities are more likely to find work. The lack of labour force in the country is a positive environment for those 
groups of people who were previously unemployed, forcing employers to recruit employees they have previously avoided employing. Despite this, a large proportion of disabled people in Latvia are not recruited due to prejudices of their employers, according to a published study by Kantar TNS (Kantar TNS, 2017).

Despite various schemes and policy measures to get disabled people into employment, they generally have much higher unemployment rates and are more likely to be underemployed (Hersh M.,2010). Disabled people are generally at the end of the queue into employment, and they, therefore, may find it easier to obtain work in conditions of high employment (Russell M., 2002). A downturn of the economy, however, means that disabled workers who have a job may be laid off. "Disabled workers are usually last in/first out," explains Peter Blanck (Russel M., 2002).

A number of different studies on the employment promotion of the disabled persons have been conducted in Latvia (Taube M., Leimane-Veldmeijere I., 2007; Zivitere M.et al., 2011a; Zivitere M. et al., 2011b; Zivitere M., Claidze V.,2011; KPMG Baltics, 2016; Baltic Institute of Social Sciences, 2017; Baltijas Konsultacijas, Agile \& CO, 2017; Kantar TNS, 2017), various conclusions and legal suggestions have been made, however, the situation has not changed significantly. Businesses operate in environments created by the interplay between economic, political and social activities. As studies show, the socialist state legacy influences the processes taking place in the society in many aspects and affects various disability policies. (Phillips S.D., 2009; Zivitere M. et al., 2011a; Mladlenov T., 2017). Because of workforce demographic changes, economic development and social activity, and because of influence of international environment, the topic of employment of people with disabilities is still on the agenda.

The research problem is how the state can support employment of people with disabilities, what kind of legal framework and policy initiatives can effectively promote employment of people with disabilities. The hypothesis of the study - the legal framework is only a precondition for the employment of disabled people. The interest of all parties concerned and partnerships with all institutions and social partners involved is a ground of effective promotion of employment of people with disabilities.

The paper examines the legal and policy frameworks of employment and anti-discrimination regulation for people with disabilities in Latvia. The aim of the paper is to study existing documents on legal and policy support system for employment of people with disabilities and the partnership between state institutions, local municipalities, non-government sector and employers. To achieve the aim, the following specific research tasks are set: 1) to study international, European Union and national level legal framework and policy documents on support for employment of people with disabilities and 2) to analyse the cooperation mechanism between key players in support of employment of disabled people.

Research methods employed: comparative and logical analysis, induction and deduction, monographic, graphic and statistical analysis. Analysis of legal acts and documentation, the content analysis of studies done, and theoretical modelling were employed to achieve the aim. Because the subject is very broad, and due to limited space for publication, the authors will focus on main legal and policy documents affecting the employment of people with disabilities, but will not make a detailed analysis of each of those documents. 


\section{Research results and discussion}

In Latvia, the first legal initiatives with regard to persons with disabilities in the workplace started back in 1990, with the regaining of the independency and development of the national legal system. The concept of equality and the principle of equal rights are the most important part of the Latvian legal system. Article 91 of the Satversme (the Constitution of Latvia) states that all people in Latvia are equal before the law and the courts (Saeima, 1922). Human rights are exercised without any discrimination.

The law On International Contracts of the Republic of Latvia, Section 13, requires that if an international treaty ratified by the Saeima (the Parliament of Latvia) contains different provisions than legal acts of the Republic of Latvia, the provisions of the international treaty shall apply (Saeima, 1994).

According to the hierarchy of legal acts, an overview of the documents regulating the employment of people with disabilities has been created (Figure 2). Legal and policy framework is grouped in four sections: international, European and national level, which summarizes both legal acts and strategic planning documents.

\section{International legal framework}

The following section outlines the relevant international legal and policy framework, including the human rights framework. All human rights are universal, indivisible, interdependent and interrelated. Persons with disability are protected by the core international human rights treaties, which protect the right to work, the right to just and favourable conditions of work, the right to equal opportunities for promotion in the workplace and the right to enjoy all other rights without discrimination: Charter of the United Nations (1945), United Nations Universal Declaration of Human Rights, (1948), Equal Remuneration Convention, 1951, Discrimination (Employment and Occupation) Convention (1958), Employment Policy Convention (1964), International Convention on Civil and Political Rights (1966), International Covenant on Economic, Social and Cultural Rights (1966), Human Resources Development Convention (1975), Declaration on the Rights of Mentally Retarded Persons (1971), United Nations Declaration on the Rights of Disabled Persons (1975), Vocational Rehabilitation and Employment (Disabled Persons) Convention (1983, Latvia has not ratified), United Nations Convention on the Rights of Persons with Disabilities (2006). The Convention on the Rights of Persons with Disabilities sets out the rights of disabled people generally and in respect of employment. In particular, article 27 of the convention protects the right to work for people with disability. Implementation of the Convention requires development of a range of policy instruments at both national and European level. The Disability Online Tool of the European Commission (DOTCOM) was developed by the Academic Network of European Disability experts (ANED) in 2011-12, in collaboration with the European Commission and the EU Member States, to map the progress being made on a range of key instruments relevant to implementation of the Convention (Priestley M., Lawson A., 2015).

Poverty denies the enjoyment of practically all human rights. The importance of international cooperation in the eradication of poverty and promotion of development is apparent (ILO, 2015). The ILO Code of Practice on Managing Disability in the Workplace (ILO, 2002) was drawn up to provide guidance to employers on practical means of implementing the types of measures contained in international instruments. While addressed mainly to employers, the Code should also prove of considerable benefit to governments, which play a primary role in providing the necessary 
legislative framework for promoting equal opportunities and treatment in the workplace (ILO, 2015).

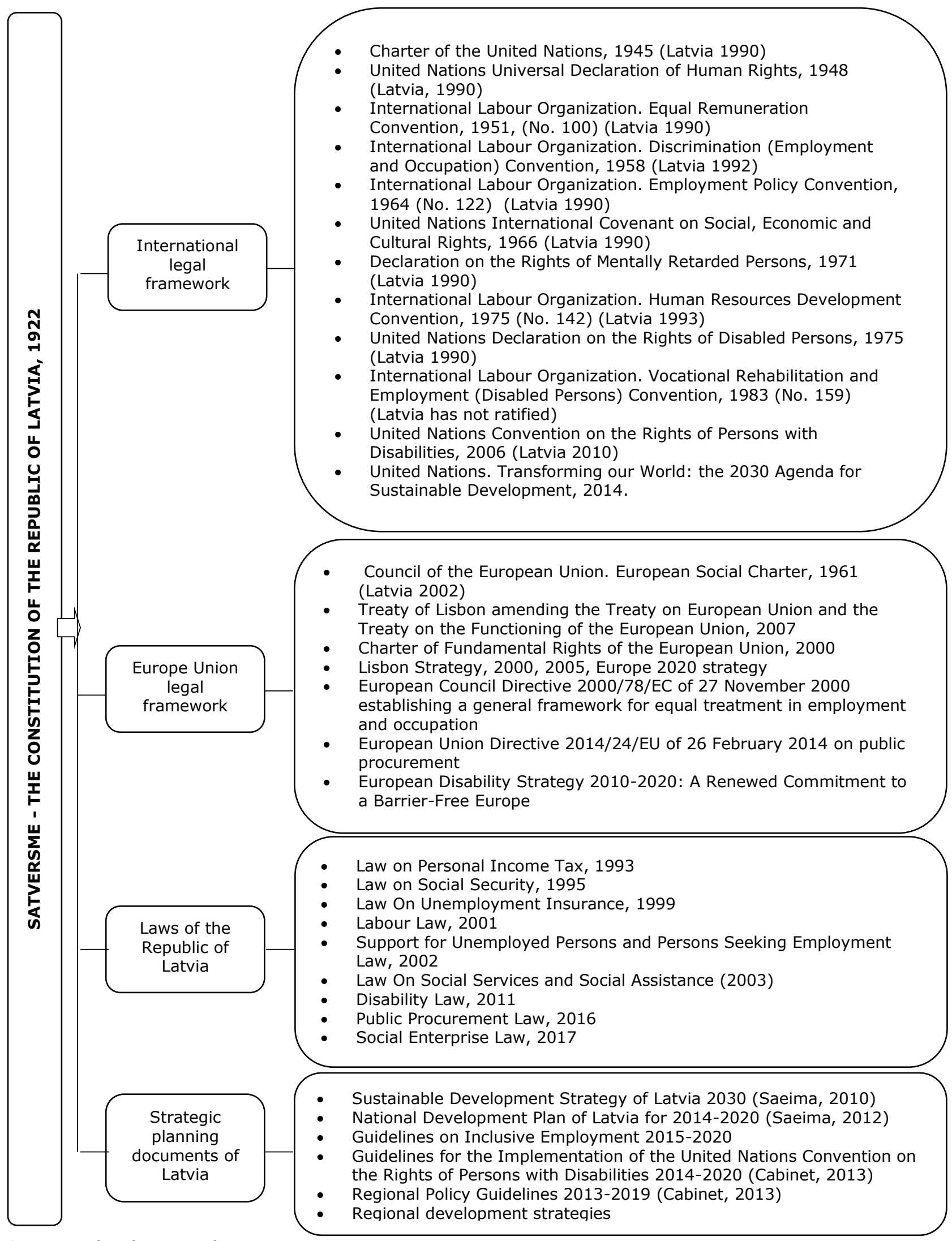

Source: authors' construction

Fig. 2. Legal and policy framework of employment for people with disabilities in Latvia 
Human rights protection and anti-discrimination conventions have been explained from theories of social justice and equality (Miller D, 1991; Sen A., 2004; Muir E., 2015). As Stein M.A (Stein M.A., 2007) points out, each of core United Nations treaties theoretically applies to disabled persons in varying degrees, but are rarely applied in practice. Although these conventions have a declarative character and their impact on the employment of people with disabilities has been criticized (Lord J. E., Stein M.A., 2008; Miller D., 1991; Posner E. A., 2008; Russell, M., 2002), they are a powerful instrument of international legal system. The provisions of international conventions are incorporated into the national laws.

\section{European regulation and policy}

The EU has a strong mandate to protect and promote the rights of persons with disabilities and to improve their social and economic situation. The human rights and anti-discrimination rules are embedded in the European Union legal instruments: European Social Charter (1961), Treaty of Lisbon amending the Treaty on European Union and the Treaty on the Functioning of the European Union (2007), Charter of Fundamental Rights of the European Union (2000). The Charter of Fundamental Rights of the EU states that the EU recognises and respects the right of persons with disabilities to benefit from measures designed to ensure their independence, social and occupational integration and participation in the life of the community. It also prohibits any discrimination on the basis of disability.

Since January 2011, the EU is a party to the UN Convention on the Rights of Persons with Disabilities -the first legally binding international human rights instrument to which the EU is a party. This represents a strong European commitment to promote, protect and ensure the full and equal enjoyment of all human rights by all persons with disabilities. Its articles provide clear guidance on the steps that are to be taken to ensure that development policies and programmes in any sector area (e.g. education, health, justice, and employment) are inclusive of persons with disabilities. In order to help implement the Convention, the Commission adopted the European Disability Strategy 2010-2020 (EC, 2010), which focuses on eliminating barriers in eight main areas: accessibility, participation, equality, employment, education and training, social protection, health, and external action.

Directive 2000/78 (Council, 2000) establishes a general framework for equal treatment in employment and occupation set down the challenge to eliminate discrimination in employment. Framework Directive required all EU Member States to have measures outlawing discrimination on the ground of disability. Importantly, the Directive states that "reasonable accommodation" shall be provided, i.e. that employers are to take appropriate measures, where needed, to enable a person with a disability to have access to, participate in, or advance in employment, or to provide training.

The Council and the representatives of the governments of the Member States made joint statement $(E U, 2017)$ for a new European Consensus on Development, a blueprint for aligning the Union's development policy with the 2030 Agenda for Sustainable Development (UN, 2015). In order to ensure that no one is left behind, the Consensus reiterates the EU's commitment to a rights-based approach to development cooperation. It also stresses the commitment to promote the rights of persons with disabilities and work to ensure their participation on an equal basis. 


\section{Domestic regulation and policy}

The field of law in which the most complete implementation of the principles of equal rights takes place is Labour Law (Saeima, 2001). The Labour Law provides protection against all forms of discrimination in all aspects of employment relations in public and private sectors. The Law states that everyone has equal rights to work, fair, safe and healthy working conditions, as well as fair work remuneration. Although statistical data proving discrimination based on a person's disability is not available, according to survey data, $50 \%$ of respondents believe that discrimination on the basis of disability is relatively widespread in Latvia (BISS, 2017). The Ombudsman has developed informative materials for employers to reduce prejudices and negative stereotypes about people with disabilities and promote their inclusion in society as well as in the labour market (Ombudsman, 2018).

The Labour Law sets out the obligations of employers to provide reasonable accommodation for people with disabilities. Within the state programme for subsidised employment employers receive financial support administrated by the State Employment Agency. Technical equipment and technical aids for individual use are available for people with disabilities in accordance with the Social service and social Assistance Law (2003). Individual assistance at work is available within the programme for subsidised employment, with a co-worker (programme offered by the State Employment Agency).

As studies show (Baltijas konsultacijas, Agile \& CO, 2017; Baltic Institute of Social Science, 2017), that the restrictions included in Part 2 of Article 109 of the Labour Law for the employer to terminate a contract of employment with a disabled worker, hinders not only the dismissal of the employed person, but also hinders the employment of people with disabilities as there are employers who do not want to take on the risk of employing a disabled persons. The OECD report also concludes that such policies are beneficial for employed people with disabilities, while the unemployed are hampered by access to the labour market, which overall has a negative impact (OECD, 2010).

The Disability Law (Saeima, 2011) prescribes the procedure by which a predictable disability and disability expert-examination shall be performed, as well as the aid measures necessary to reduce the risk of a disability and the consequences of a disability. There are laws that give benefits to people with disabilities: Law on Social Security (Saeima, 1995) and Law on Personal Income Tax (Saeima, 1993). The regulatory framework prescribes the person's choice to indicate information on disability in electronic work record card, as many workers do not want this information to be known by their income-paying employer, because they are afraid of discrimination. Thus, they choose to submit an annual income declaration in order to receive an overdue tax. Persons seeking for a job are supported by Support for Unemployed Persons and Persons Seeking Employment Law (Saeima, 2002).

It is expected that the new Social Enterprise Law (Saeima, 2017) will promote the employment of people with disabilities. According to European Directive 2014/24/EU on public procurement (EC, 2014), the Public Procurement Law of Latvia (Saeima, 2016) gives privileges for entrepreneurs who employ people with disabilities. What concerns social entrepreneurship, it is planned to include social entrepreneurs as the subjects of privileged rights agreements.

Obligatory employment quotas are an example for legislative instruments that accelerate active labour market policy - the integration of persons with disabilities into the open labour market. 
Latvia does not have a quota system yet, but discussions are underway on how to implement the quota system in Latvia.

For employers' motivation to employ disabled people State Employment Agency offers projects on subsidized jobs. However, it should be emphasized that these instruments are introduced for a certain period; therefore, there is a general lack of a system of employer motivation for employment of disabled people in the country. Activities for the inclusion of people with disabilities into the labour market lack succession and continuity. They are most often implemented through projects supported by EU financial instruments rather than based on a defined national long-term policy with adequate funding. In addition, participation in existing activities often involves a large bureaucratic burden.

The Guidelines on the Implementation of the UN Convention on the Rights of Persons with Disabilities 2014-2020 (Cabinet, 2013) provide actions towards inclusion of disabled persons into labour market by provision of appropriate support, taking into account the type of functional disorder. All strategic planning documents: Sustainable Development Strategy of Latvia until 2030 (Saeima, 2010), the National Development Plan of Latvia 2014-2020 (Saeima, 2012), the Guidelines on Inclusive Employment 2015-2020 (Cabinet, 2015) and Regional Policy Guidelines for 2013-2019 (Cabinet, 2013) contain inclusive society principles for people with disabilities. After examining the regional documents, it was concluded that regional development strategies do not mention any policies for inclusion people with disabilities into the labour market (Skestere I., 2011; Vahlina T., 2011). The same applies to municipal planning documents.

\section{Key players and co-operation}

More people with disability could work if they were helped with the right supports at the right time. As the OECD points out in its study, much can be gained from improvements in three areas: better cross-agency co-operation; systematic and tailored engagement with clients; and improved institutional incentives (OECD, 2010).

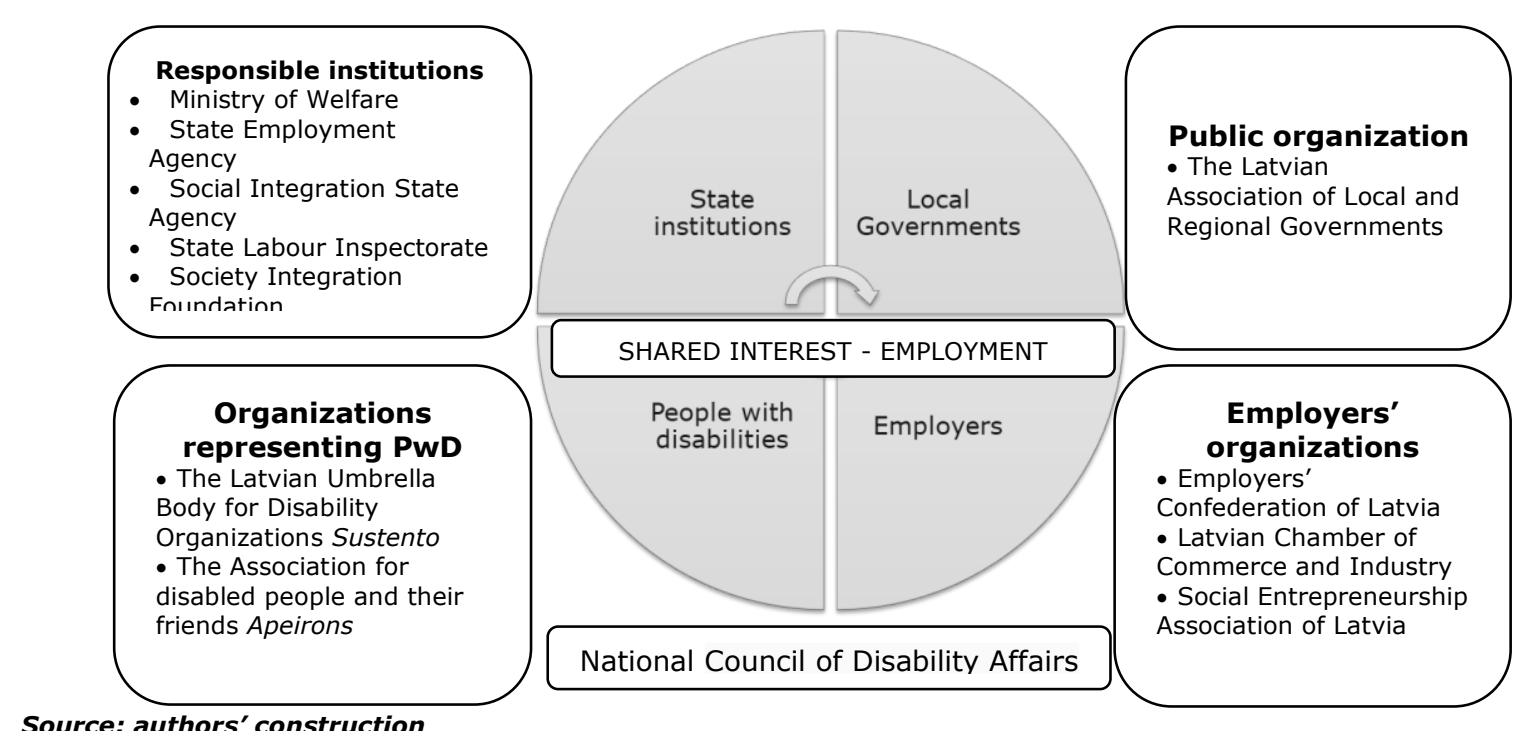

Fig. 3. Key players in employment of people with disabilities

The key players, whose shared interest is employment of disabled people in Latvia, are responsible state institutions, local governments, non-governmental organizations representing 
interests of people with disabilities, and employers - state and local government owned enterprises, private business and social enterprises (Figure 3). The Ministry of Welfare is the leading state administration institution in the field of equal opportunities for people with disabilities in Latvia (Cabinet, 2004a). The following state institutions operate under the subordination of the Ministry: the State Employment Agency, the Social Integration State Agency, the State Labour Inspectorate and the State Social Insurance Agency (Cabinet, 2004a). The coordination mechanism within the Government is not formally established. It is carried out through the National Council of Disability Affairs (Cabinet, 2004b). This Council involves line ministers, Ombudsman, Chairperson of the Latvian Association of Local and Regional Governments, Director of Society Integration Foundation, President of Free Trade Union Confederation of Latvia, Director General of Employers' Confederation of Latvia and representatives of key non-governmental organisations representing people with disabilities such as Apeirons, Latvian Association of Deaf, Latvian Society of the Blind, and others. The Council is a consultative body involved in the design and implementation of the policy of integration of people with disabilities.

The Ministry of Welfare coordinates the implementation of the Convention on the Rights of Persons with Disabilities (Cabinet, 2013) and the implementation of the guidelines for inclusive employment (Cabinet, 2015). The implementation of the Convention is monitored by the Ombudsman - an independent institution whose function is to encourage individuals to contribute to the protection of human rights and compliance with the principle of equal treatment and the prevention of any kind of discrimination. Other ministries (for example, the Ministry of Education and Science, the Ministry of Health, the Ministry of Traffic and others) are responsible for the implementation of specific activities according to the sphere of their competence.

Starting with ministerial level, there are, in general a number of public bodies that work on the integration or inclusion of persons with disabilities in the labour market, which indicates the horizontal nature of the disability policy. This may lead to problems relating to the different understanding of the needs of persons with disabilities and, therefore, inter-institutional communication and cooperation play an important role in the coordinated implementation of disability policies.

The most important player for employment people with disabilities is employer. As various studies show, employers are not interested in employing people with disabilities (KPMG Baltics, 2016; Kantar TNS, 2017). The main obstacle presented is strict labour law, which is not motivating the employer. It comes to the conclusion that most people with disabilities are employed by the companies that have developed socially responsible personnel policy.

The role of local authorities to promote employment for people with disabilities has not been efficiently studied. The local municipalities in co-operation with community based NGOs play very significant role in social inclusion. Local governments are more involved in providing social services rather than promoting employment for people with disabilities. According to the survey of municipalities (BISS, 2015; Ombudsman, 2016), only $30 \%$ of the local governments provides support for the creation of subsidized jobs or special workshops for people with disabilities. Only two municipalities have established special support programs for persons with disabilities for commencing and conducting entrepreneurship. Among other measures, several municipalities has created jobs in their institutions, support groups for people with disabilities, which are working to increase the motivation of people with disabilities and strengthen self-confidence in order to return 
disabled people to the active labour market, some has set up cooperation with local entrepreneurs (ibid.).

Analysing the interests, objectives, programs and activities of each stakeholder, one has to conclude that the existing support mechanism of the regulatory and policy framework has not had a significant impact on employment growth of people with disabilities.

\section{Conclusions, proposals, recommendations}

1) There are various laws and regulations, various targeted initiatives, but small and slow impacts on employment of people with disabilities in Latvia. Along with the legal framework, it is necessary to find an effective support mechanism for the inclusion of people with disabilities in the labour market.

2) Although the Labour law Article 109 was intended to protect people with disabilities, it has become an obstacle for the employer to employ disabled people, on the one hand, while it is a barrier for people with disabilities to enter the free labour market, on the other.

3) Regarding the critical factors in employing disabled people, employers are not motivated to employ people with disabilities. The existing legal norms are bureaucratic and little help in adapting workplaces that do not encourage motivation to employ disabled workers.

4) At the regional and municipal level, initiatives for the employment of disabled people are not planned efficiency; municipalities focus more on social services. It is necessary to strengthen community - based approach for inclusive employment.

5) A motivating cooperation mechanism between the various stakeholders - state institutions, employers, local governments, non-governmental organizations - should be created.

6) An open question is what can be expected from the new Social enterprise law and how it will affect the employment of people with disabilities.

7) The Ministry of Welfare is working on the introduction of a quota system, which is judged sceptically by employers. Future studies should examine how quotas will affect the labour market for people with disabilities and whether the quota system evolves as a motivating tool for employers.

\section{Bibliography}

1. Academic Network of European Disability experts (ANED). DOTCOM: the Disability Online Tool of the Commission. Retrieved: http://www.disability-europe.net/dotcom. Access: 01.02.2018.

2. Baltic Institute of Social Sciences (BISS) (2015). Study contractor Ombudsman. ANO konvencijas par personu ar invaliditati tiesibam monitorings 2010 - 2014. Pasvaldību aptaujas rezultati (Monitoring the UN Convention on the Rights of Persons with Disabilities 2010-2014. Results of the Local Government Survey). Retrieved:http://www.tiesibsargs.Iv/uploads/content/legacy/ANO_invaliditates_konvencija_Latvijas_pasvald ibu_aptauja_2015.pdf. Access: 02.02.2018.

3. Baltic Institute of Social Sciences (BISS) (2017). Motivacijas paaugstinasanas un atbalsta pakalpojumu potencialas merka grupas profilesana un vajadzibu izpete (Profiling of potential target groups for motivation and support services and the needs assessment study). Retrieved: http://www.sif.gov.Iv/images/files/nodevumi/ESF_Da \%C5 \%BE \%C4 \%81d \%C4 \%ABbas/Motivacijas_paa ugstinasana/Gala_zinojums.pdf. Access: 03.02.2018.

4. Baltijas Konsultacijas, Agile \& CO (2017). Petijums par starptautisko praksi personu ar invaliditati atbalsta sistemu joma (Study on international practice in the field of support systems for people with disabilities). Riga,p.578. Retrieved: http://www.Im.gov.Iv/upload/projekts/1_nodevums.pdf. Access 20.01.2018.

5. Cabinet of Ministers (1997). Ministru kabineta noteikumi Nr. 138 (Cabinet Regulation No.138. Noteikumi par iedzivotaju ienakuma nodokla papildu atvieglojumiem personam ar invaliditati, politiski represetajam personam un nacionalas pretosanas kustibas dalibniekiem (Regulations on supplementary personal income tax relief for persons with disabilities, politically repressed persons and members of the national resistance movement). Latvijas Vestnesis, 11.04.1997.Nr 94 (809).

6. Cabinet of Ministers (2004a). Ministru kabineta noteikumi Nr. 49. (Cabinet Regulation No.49). Labklajibas ministrijas nolikums (Regulation of the Ministry of Welfare). Latvijas Vestnesis, 30.01.2004. Nr.16(2964). 
7. Cabinet of Ministers (2004b). Ministru kabineta noteikumi Nr. 561 (Cabinet Regulation No.561). Invaliditates lietu nacionalas padomes nolikums (Regulation on National Council of Disability Affairs). Latvijas Vestnesis, 01.07.2004. Nr.103 (3051).

8. Cabinet of Ministers (2013). Ministru kabineta rikojums Nr. 496 (Order No. 496). Regionalas politikas pamatnostadnes 2013.-2019.gadam (Regional Policy Guidelines for 2013-2019). Latvijas Vestnesis, 30.10.2013. Nr.212(5018).

9. Cabinet of Ministers (2013). Ministru kabineta rikojums Nr. 564 (Order No. 564). Apvienoto Naciju Organizacijas Konvencijas par personu ar invaliditati tiesibam istenosanas pamatnostadnes 2014.2020.gadam (The Guidelines for the Implementation of the United Nations Convention on the Rights of Persons with Disabilities 2014-2020). Latvijas Vestnesis, 26.11.2013. Nr.231(5037).

10. Cabinet of Ministers (2015). Ministru kabineta rikojums Nr. 561 (Order No. 561). Par Ieklaujošas nodarbinatibas pamatnostadnem 2015.-2020.gadam (The Guidelines on Inclusive Employment 2015-2020). Latvijas Vestnesis, 14.05.2015. Nr. 93 (5411).

11. Council of Europe (1961). European Social Charter. Retrieved: https://www.coe.int/en/web/conventions/full-list/-/conventions/treaty/035. Access: 20.12.2017.

12. Council of the European Commission (Council) (2000). Equal treatment in employment and occupation. Council Directive 2000/78/EC of 27 November 2000. Retrieved: http://eur-lex.europa.eu/legalcontent/en/TXT/?uri=CELEX:32000L0078. Access: 02.01.2018.

13. European Commission (2008). Non-discrimination and equal opportunities: A renewed commitment. Retrieved: http://eur-lex.europa.eu/legal-content/en/TXT/?uri=CELEX:52008DC0420. Access: 02.01.2018.

14. European Commission (2008). Proposal for a Council Directive on implementing the principle of equal treatment between persons irrespective of religion or belief, disability, age or sexual orientation. Retrieved: http://www.equalrightstrust.org/content/proposal-council-directive-implement-principle-equal-treatmentbetween-persons-irrespectivef. Access: 20.01.2018

15. European Commission (2010).European Disability Strategy 2010-2020: A Renewed Commitment to a Barrier-Free Europe. Brussels. Retrieved: http://eur-lex.europa.eu/legalcontent/EN/TXT/?uri=LEGISSUM:em0047. Access: 20.01.2018.

16. European Commission (2017). Progress Report on the implementation of the European Disability Strategy (2010 - 2020). Retrieved: http://ec.europa.eu/social/main.jsp?langId=en\&catId=89\&newsId=2725. Access: 02.03.2018.

17. European Economic and Social Committee (2017). Opinion of the European Economic and Social Committee on "Concluding observations of the UN CRPD Committee - A new strategy for persons with disabilities in the European Union" Retrieved: http://eur-lex.europa.eu/legal-

content/EN/TXT/?uri=uriserv \%3AOJ.C_.2017.034.01.0015.01.ENG Access: 05.02.2018.

18. European Parliament and Council (2014). Directive 2014/24/EU on public procurement and repealing Directive 2004/18/EC. Retrieved: http://eur-lex.europa.eu/legalcontent/EN/TXT/HTML/?uri=CELEX:32014L0024\&from=LV. Access: 20.02.2018.

19. European Parliament, Council, Commission (EU) (2012). Charter of Fundamental Rights of the European Union. Retrieved: http://eur-lex.europa.eu/legal-content/EN/TXT/?uri=CELEX \%3A12012P \%2FTXT. Access: 26.12.2017.

20. European Parliament, Council, Commission (EU) (2017). The New European Consensus on Development "Our World, Our Dignity, Our Future". Retrieved: https://ec.europa.eu/europeaid/new-european-consensusdevelopment-our-world-our-dignity-our-future_en, Access: 03.12.2017.

21. European Union (EU) (2007). Treaty of Lisbon. Amending The Treaty on European Union and the Treaty Establishing the European Community. Retrieved: http://eur-lex.europa.eu/legalcontent/EN/TXT/?uri=celex \%3A12007L \%2FTXT, Access: 03.02.2018

22. Eurostat (2011). Disability statistics. Retrieved: http://ec.europa.eu/eurostat/statisticsexplained/index.php/Disability_statistics. Access: 03.02.2018

23. Hersh, M. (2010). Disabled People and Employment: Barriers to Potential Solutions. In: Moss, G. ed. Profiting from diversity: the business advantages and the obstacles to achieving diversity. UK: Palgrave Macmillan, pp.215 - 240.

24. International Labour Organization (ILO) (2015). Decent work for persons with disabilities: promoting rights in the global development agenda. International Labour Office, Geneva, Switzerland, Retrieved: http://www.ilo.org/wcmsp5/groups/public/---ed_emp/---

ifp_skills/documents/publication/wcms_430935.pdf. Access: 01.02.2018.

25. International Labour Organization (ILO) (1975). Human Resource Human Resources Development Convention No. 142. Retrieved:

http://www.ilo.org/dyn/normlex/en/f?p=NORMLEXPUB:12100:0::NO::P12100_INSTRUMENT_ID:312287. Access: 26.12.2017.

26. International Labour Organization (ILO) (2002). Managing disability in the workplace. International Labour Office, Geneva, p. 41.

27. KPMG Baltics (2016). Darba tirgus pieprasijuma izpete un darba tirgus vajadzibam nepieciesamo profesiju un prasmju noteiksana personam ar smagu invaliditati un gariga rakstura traucejumiem. Retrieved:http://petijumi.mk.gov.Iv/sites/default/files/title_file/petijums_darba_tirgus_pieprasijuma_izpete _un_darba_tirgus_vajadz_nepiec_profes_un_prsmj_noteiks_personam_ar_ivalid.pdf. Access: 01.02.2018.

28. Kantar TNS (2017). Ieklaujosas darba vides un dazadibas vadibas principu ieviesana darbavietas Latvija: Darba deveju aptaujas galarezultatu apkopojums (Implementation of inclusive work environment and 
diversity management principles in workplaces: Survey of employers). Retrieved:http://www.sif.gov.Iv/images/files/ESF/ESFintegracija/petijumi/Aptaujas_gala_rezultatu_apkopojums-Analize.pdf. Access: 02.03.2018.

29. Lord, J. E., Stein, M. A. (2008). The Domestic Incorporation of Human Rights Law and the United Nations Convention on the Rights of Persons with Disabilities. Washington Law Review. Vol. 83:449.

30. Miller, D (1991). Recent Theories of Social Justice. British Journal of Political Science. Cambridge University Press, Vol. 21, No. 3 (Jul., 1991), pp. 371-391. Retrieved:

https://sustainability.water.ca.gov/documents/18/3407876/Recent+Theories+of+Social+Justice.pdf . Access: 02.02.2018.

31. Mladlenov, T. (2017). Postsocialist disability matrix. Scandinavian Journal of Disability Research, 19:2, 104117.

32. Muir, E. (2015). Pursuing Equality in the EU. The Oxford Handbook of European Union Law, Oxford University Press, Oxford Handbooks online.

33. Nodarbinatibas valsts agentura (NVA) (State Employment Agency). Available at: http://www.nva.gov.Iv

34. OECD (2010). Sickness, Disability and Work: Breaking The Barriers. A Synthesis of Findings across OECD Countries. Paris: OECD Publishing, p.166.

35. Ombudsman of Latvia (2016). Latvijas Republikas tiesibsarga 2015.gada zinojums (Report of the Ombudsman of the Republic of Latvia for 2015). Retrieved:

http://www.tiesibsargs.Iv/uploads/content/legacy/Tiesibsarga_2015_gada_zinojums.pdf. Access: 02.02.2018.

36. Ombudsman of Latvia (2018). Latvijas Republikas tiesibsarga 2017.gada zinojums (Report of the Ombudsman of the Republic of Latvia for 2017). Retrieved: http://www.tiesibsargs.Iv/lv/pages/petijumi-unpublikacijas/gadazinojumi/gada-zinojumi. Access: 15.03.2018.

37. Phillips, S.D. (2009). "There Are No Invalids in the USSR!": A Missing Soviet Chapter in the New Disability History Disability Studies Quarterly 29 (3). Retrieved: http://www.dsq-sds.org/article/view/936/1111. Access: 23.01.2018.

38. Posner, E. A. (2008). Human Welfare, Not Human Rights. John M. Olin Program in Law and Economics Working Paper No. 394, University of Chicago Law School. Retrieved:

https://chicagounbound.uchicago.edu/cgi/viewcontent.cgi?article=1244\&context=law_and_economics. Access: 02.03.2018.

39. Priestley, M and Lawson, A (2015). Mapping disability policies in Europe: Introducing the disability online tool of the commission (DOTCOM). ALTER - European Journal of Disability Research, 9 (1). pp. 75-78.

40. Russell, M (2002). What disability civil rights cannot do: Employment and political economy, Disability and Society, $17(2), 117-137$.

41. Saeima (Parliament of Latvia) (2001). Darba likums (Labor law). Latvijas Vestnesis, 06.07.2001.Nr.105 (2492).

42. Saeima (Parliament of Latvia) (2010). Konvencija par personu ar invaliditati tiesibam (Convention on the Rights of Persons with Disabilities). Latvijas Vestnesis, 17.02.2010. Nr. 27 (4219).

43. Saeima (Parliament of Latvia) (2010). Latvijas ilgtspejigas attistibas strategija lidz 2030 (Sustainable Development Strategy of Latvia until 2030). Latvijas Vestnesis, 29.06.2010. Nr.101(4293).

44. Saeima (Parliament of Latvia) (2012). Latvijas Nacionalais attitsibas plans 2014-2020 (National Development Plan of Latvia for 2014-2020). Latvijas Vestnesis, 09.01.2013. Nr.6(4812).

45. Saeima (Parliament of Latvia) (1922). Latvijas Republikas Satversme (The Constitution of the Republic of Latvia). Latvijas Vestnesis, 01.07.1993. Nr.43.

46. Saeima (Parliament of Latvia) (1993). Likums par iedzivotaju ienakumu nodokli (Law on Personal Income Tax). Latvijas Vestnesis, 01.06.1993. Nr. 32.

47. Saeima (Parliament of Latvia) (1995). Likums par socialo drosibu (On Social Security). Latvijas Vestnesis, 21.09.1995. Nr. 144(427).

48. Saeima (Parliament of Latvia) (1999). Par apdrosinasanu bezdarba gadijumam (On Unemployment Insurance), Latvijas Vestnesis, 15.12.1999. Nr. 416/419 (1876/1879).

49. Saeima (Parliament of Latvia) (1994). Par Latvijas Republikas starptautiskajiem ligumiem (On international treaties of the Republic of Latvia), Latvijas Vestnesis, 26.01.1994. Nr. 11(142).

50. Saeima (Parliament of Latvia) (2016). Publisko iepirkumu likums (Public Procurement Law). Latvijas Vestnesis, Nr 254 (5826) 29.12.2016.

51. Saeima (Parliament of Latvia) (2002). Socialo pakalpojumu un socialas palidzibas likums (Law On Social Services and Social Assistance). Latvijas Vestnesis, 19.11.2002. Nr. 168 (2743).

52. Saeima (Parliament of Latvia) (2017). Sociala uznemuma likums (Social Enterprise Law). Latvijas Vestnesis, 25.10.2017Nr. 212 (6039).

53. Sen, A. (2004). Elements of a Theory of Human Rights. Philosophy \& Public Affairs, 32, no. 4, pp. 315-356.

54. Skestere, I. (2011). Nacionalo un regionalo politikas planosanas dokumentu socialas ieklausanas un socialo pakalpojumu cilvekiem ar invaliditati joma sasaites ar ANO Konvenciju par personu ar invaliditati tiesibam analize. (Analysis of national and regional policy planning documents for social inclusion and social services for people with disabilities in line with the UN Convention on the Rights of Persons with Disabilities.) Riga, Retrieved:http://www.Ikndz.Iv/lv/box/files/filelists/1334735308-planosanasdokumentuanalize2.pdf. Access: 03.08.2017. 
55. Stein, M. A. (2007). Disability Human Rights. Cornell University ILR School. California Law Review, Vol.95:75-122. Retrieved:

https://digitalcommons.ilr.cornell.edu/gladnetcollect/450/?utm_source=digitalcommons.ilr.cornell.edu \%2F gladnetcollect \%2F450\&utm_medium=PDF\&utm_campaign=PDFCoverPages. Acess:02.02.2018.

56. Taube, M., Leimane-Veldmeijere, I. (2007). Promotion of the Employment opportunities for People with Intellectual Disabilities and Psychiatric Illnesses in Latvia. Centre for psychiatry and narcology, Riga, p. 47.

57. United Nations (UN) (2006). Convention on the Rights of Persons with Disabilities (CRPD). Retrieved:https://www.un.org/development/desa/disabilities/convention-on-the-rights-of-persons-withdisabilities.html. Access: 20.12.2017.

58. United Nations (UN)(2007). Overview of International Legal Frameworks For Disability Legislation. Retrieved: http://www.un.org/esa/socdev/enable/disovlf.htm. Access: 08.02.2018.

59. United Nations (UN)(2015).Transforming our world: the 2030 Agenda for Sustainable Development. Retrieved: https://sustainabledevelopment.un.org/post2015/transformingourworld. Access: 15.01.2018.

60. United Nations (UN) (2018). The United Nations and Disability: 70 years of the work towards a more inclusive world. (2018). New York, Retrieved: https://www.un.org/development/desa/disabilities/wpcontent/uploads/sites/15/2018/01/History_Disability-in-the-UN_jan23.18-Clean.pdf. Access: 08.02.2018.

61. Vahlina, T. (2011). Nacionalo un regionalo politikas planosanas dokumentu socialas ieklausanas un socialo pakalpojumu cilvekiem ar invaliditati joma analize (Analysis of national and regional policy planning documents for social inclusion and social services for people with disabilities). Retrieved: http://www.lkndz.lv/lv/box/files/filelists/1334735277-planosanasdokumentuanalize1.pdf. Access: 03.08.2017.

62. Zivitere, M., Boubaris, T., Dzhiuginta Valeckiene, D., Bencivenga, R., Zivitere, A.L., Oborenko, Z., Tinti, A., Satiene, S. (2011a). Distance Education Course: Ability not Disability in Workplace. AnDiw. ISMA, Riga, p. 174.

63. Zivitere, M., Boubaris, T., Dzhiuginta Valeckiene, D., Bencivenga, R., Zivitere, A.L., Oborenko, Z., Tinti, A., Satiene, S. (2011b). Integrating Disabled People into Workplace. Annex to the Distance Education Cource: Ability not Disability in Workplace. AnDiw. ISMA, Riga, p. 195.

64. Zivitere, M., Claidze, V. (2011). Legal environment, national strategies and policies for employment of people with disabilities. SEER: Journal for Labour and Social Affairs in Eastern Europe, Vol. 14, No. 1, pp. $119-130$ 